\title{
Hydrogeochemistry and groundwater quality assessment of Ranipet industrial area, Tamil Nadu, India
}

\author{
G TAmma RaO ${ }^{1, *}, \mathrm{~V}$ V S Gurunadha $\mathrm{RAO}^{1}$ and $\mathrm{K}$ Ranganathan ${ }^{2}$ \\ ${ }^{1}$ National Geophysical Research Institute (CSIR), Hyderabad 500 606, Uppal Road, India. \\ ${ }^{2}$ Central Pollution Control Board, Zonal Office (South), Bangalore, India. \\ *Corresponding author.e-mail: gopingri@gmail.com
}

\begin{abstract}
One of the highly polluted areas in India located at Ranipet occupies around 200 tanneries and other small scale chemical industries. Partially treated industrial effluents combined with sewage and other wastes discharged on the surface cause severe groundwater pollution in the industrial belt. This poses a problem of supply of safe drinking water in the rural parts of the country. A study was carried out to assess the groundwater pollution and identify major variables affecting the groundwater quality in Ranipet industrial area. Twenty five wells were monitored during pre- and post-monsoon in 2008 and analyzed for the major physico-chemical variables. The water quality variables such as total dissolved solids (TDS), Iron $\left(\mathrm{Fe}^{2+}\right)$, Hexavalent Chromium $\left(\mathrm{Cr}^{6+}\right)$, at most of the sampling locations exceeded the ISI and WHO guideline levels for drinking water. Multivariate statistical techniques such as factor analysis were applied to identify the major factors (variables) corresponding to the different source of variation in groundwater quality. The water quality of groundwater is influenced by both anthropogenic and chemical weathering. The most serious pollution threat to groundwater is from TDS, $\mathrm{Cr}^{6+}$ and $\mathrm{Fe}^{2+}$, which are associated with sewage and pollution of tannery waste. The study reveals that the groundwater quality changed due to anthropogenic and natural influences such as agricultural, natural weathering process.
\end{abstract}

\section{Introduction}

Rapid growth of urban population, development of agriculture and industrial activities especially in hard rock terrains caused an intense increase in water consumption. Overexploitation together with a decrease in precipitation and water table decline are the most serious problems for the quality of groundwater in urban areas with highly dense population. Particularly, the process of tanning involves the use of large amounts of water and various chemicals like lime, sodium-carbonate, sodiumbi-carbonate, common salt, sodium-sulphate and chrome-sulphate. It is established that a single tannery can cause the pollution of groundwater around the radius of 7-8 km (CLRI 1990; Ansari et al. 1999). Chromium present in effluent is primarily in the less toxic trivalent form $\left(\mathrm{Cr}^{3+}\right)$ but when this effluent is discharged into the soil, due to varying environmental conditions, $\mathrm{Cr}^{3+}$ is oxidized to toxic hexavalent form, which seldom remains as $\mathrm{Cr}^{6+}$ (Anderson 1999; Selvakumar and Manoharan 2002; Srinivasa Gowd et al. 2005; Thangarajan et al. 1999; Mondal and Singh 2005). Several authors have reported about the presence of contaminants in soils (Wu 1980) and waters (Kolpin et al. 1998) in various part of the globe and also in India (Srinivasa Rao et al. 1997; Elango et al. 2003). Contamination of the groundwater by domestic, industrial effluents and agricultural activity is a serious problem faced by developing countries.

Keywords. Hydrochemistry; quality analysis; factor analysis; groundwater quality assessment. 
The conventional methods (histograms, trilinear, semi-logarithmic) deal with a limited number of variables that are responsible for the groundwater chemistry (Matthess 1982; Hem 1989). Multivariate analyses, such as cluster and factor analyses, are used to incorporate larger number of variables measured in groundwater systems. Factor analysis is used simply as a numerical method of discovering variables that are more important than other data for representing parameter variation or demonstrating hydrochemical processes. The basic purpose of factor analysis is to study the hydrogeochemistry of an aquifer and explain a large amount of the variance of the analytical data by a small number of factors (Ruiz et al. 1990). Factor analysis has been successfully applied to clarify the contributing hydrogeological and hydrogeochemical processes that result in the quality of water observed during aquifer monitoring (Usunoff and Guzman 1989; Razack and Dazy 1990; BrizKishore and Murali 1992; Suk and Lee 1999). In the present context of study, particular emphasis is

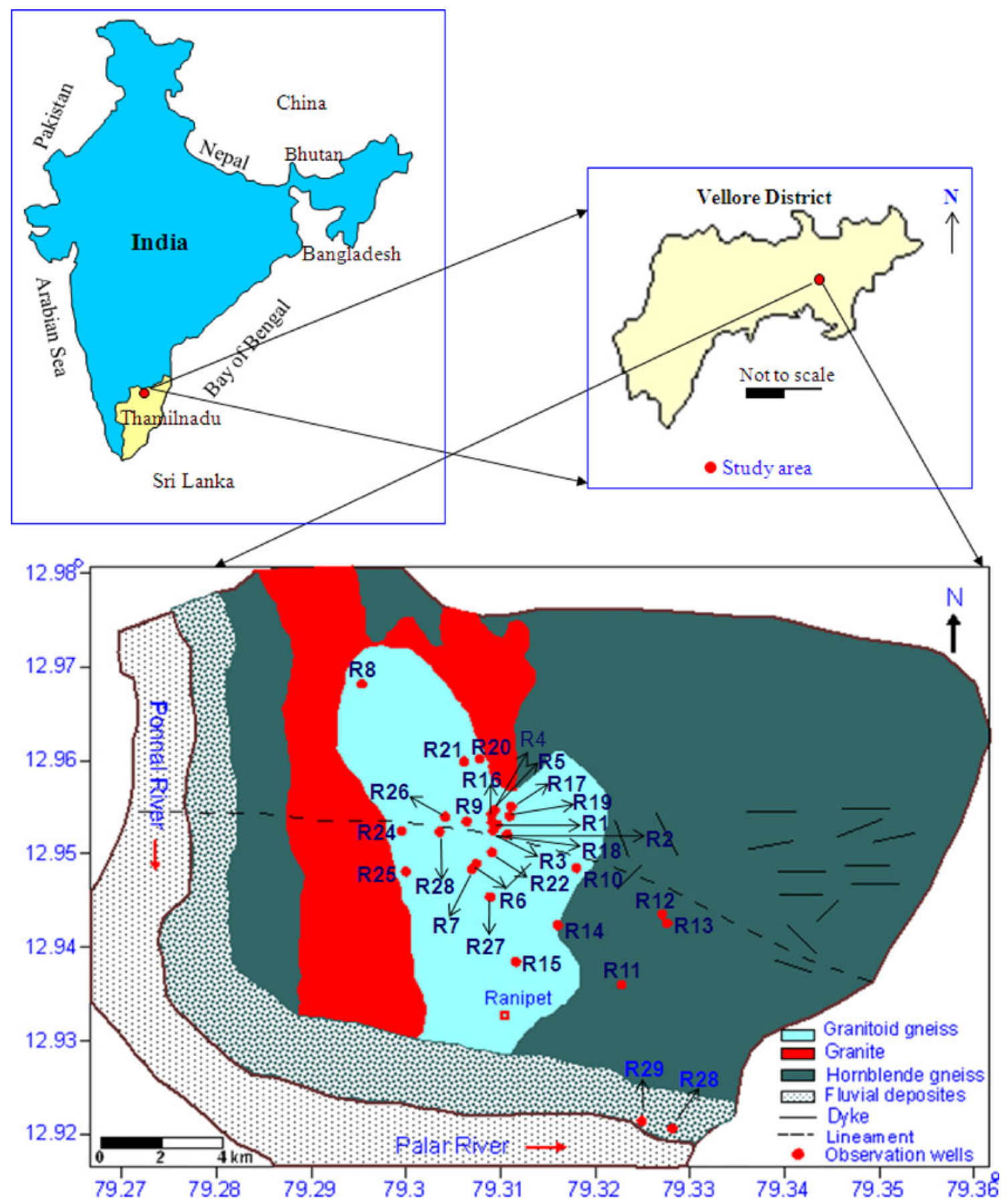

Figure 1. Location of observation wells and geology map of the study area. 
placed on the status of groundwater pollution due to the effluents of chemical manufacturing industries and tannery industries in the study area. To keep this view in mind that textile and tannery industries are the major source of pollution and contributors of metals to the environment, a systematic study was required to ascertain the status of chemical constituents and metals in textile and tannery effluents and associated groundwater. Therefore, this study aimed to assess the current state of water quality and identify the major factors affecting on water quality of groundwater in the Ranipet industrial area.

\section{Study area}

The study area is located in $79^{\circ} 26^{\prime} 45^{\prime \prime}-79^{\circ} 37^{\prime} 69^{\prime \prime} \mathrm{E}$ longitude and $12^{\circ} 92^{\prime} 25^{\prime \prime}-12^{\circ} 98^{\prime} 87^{\prime \prime} \mathrm{N}$ latitude and the watershed covering the study area spread over $54 \mathrm{~km}^{2}$ (figure 1). It is one of the biggest exporting centers of tanned leather in India and discharging their effluents on the open land and surrounding water bodies (Govil et al. 2004). All tannery industries located in Ranipet are discharging effluents into Puliankannu, Karai, Puliathengal, Vanapadi, and Thandalam lakes and it is a matter of increasing concern, as these industries are located in Palar River Basin.

\section{Geology and geohydrology}

The study area predicts undulating topography, falling in pediment zone and structural hills in the northern side. The flat to undulating pediplain nature continue and extends up to the flood plain of Palar River. The pediplain has granites, gneisses and basic and ultra basic intrusive, which are discontinuous unconfined to semi-confined aquifers down to $150 \mathrm{~m} \mathrm{bgl}$ and restricted to weathered zone and fractures GSI (2000). The major dolerite dyke, striking NE-SW passes through the factory area (Sankaran et al. 2009). Quaternary sediments are restricted to the alluvial sand and clay of the Palar River and its tributaries. Sand thickness in the Palar River is hardly $10 \mathrm{~m}$ and the width being $2000 \mathrm{~m}$ along the river course (Rao et al. 2009). The alluvium consisting of fine to coarse sand and clay occurring in the area is of a fluviatile origin and restricted to the course of Palar River and major streams (Subramanian and Selvan 2001). Discontinuous unconfined to semi-confined aquifers down to $150 \mathrm{~m} \mathrm{bgl} \mathrm{restricted} \mathrm{to} \mathrm{weathered} \mathrm{zone} \mathrm{and} \mathrm{frac-}$ ture zone have been encountered in the granite and gneissic formations in the Palar basin (figure 1).

\section{Materials and methods}

A total of 25 representative groundwater samples were collected for two different seasons, viz., pre-monsoon (June) and the post-monsoon (December) along with a maximum representation covering the entire study area (figure 1). Groundwater samples were collected in $1000 \mathrm{ml}$ polythene bottles pre-cleaned with double distilled water. The collected samples were filtered by Whatman filter paper prior to their analysis in the laboratory. The samples were analyzed for all major ions by following standard methods (APHA 1998) including Hexavalent chromium $\left(\mathrm{Cr}^{6+}\right)$ for both pre- and post-monsoon during 2008 (figure 1). $\mathrm{pH}$, TDS and EC were measured by water quality analyzer (Systronics Model 371). $\mathrm{SO}_{4}^{2-}$ was determined by digital spectrophotometer model GSS 700A (Electronic Corporation of India). $\mathrm{Ca}^{2+}$ and $\mathrm{Mg}^{2+}$ were analyzed by EDTA titration. Chloride $\left(\mathrm{Cl}^{-}\right)$was determined by ion selective electrode method (Cole-Parmer iodine electrode, model no. 27502-13). Bicarbonate $\left(\mathrm{HCO}_{3}^{-}\right)$concentrations of the groundwater were determined by potentiometric titration method. $\mathrm{SO}_{4}^{2-}$ was determined by digital spectrophotometer model GSS 700A (Electronic Corporation of India). Nitrate $\left(\mathrm{NO}_{3}^{-}\right)$was measured by using ion selective electrode method (Cole-Parmer iodine electrode, model no. 2750219). Total hardness $(\mathrm{TH})$ of the groundwater was calculated using the formula given by Sawyer et al. (2003):

$$
\mathrm{TH}\left(\text { as } \mathrm{CaCO}_{3}\right) \mathrm{mg} / \mathrm{L}=\left(\mathrm{Ca}^{2+}+\mathrm{Mg}^{2+}\right) \times 50
$$

where the concentrations of $\mathrm{Ca}^{2+}$ and $\mathrm{Mg}^{2+}$ are represented in meq/l.

The $\mathrm{Cr}^{+6}$ and $\mathrm{Fe}^{2+}$ concentrations in samples were determined colorimetrically by using spectrophotometer at $540 \mathrm{~nm}$ by diphenyl carbazide (DPC) method (APHA 1998).

Factor analysis and derivative methods have been widely used in geochemical applications to identify pollution sources and to apportion natural vs. human contributions (Chen et al. 2005). Factor analysis is a multivariate technique designed to analyse the interrelationships within a set of variables. The factors are chosen in such a way that it reduces the overall complexity of the data by taking advantages of inherent interdependencies (Davis 2002). To undertake factor analysis (FA), the SPSS (predictive analytics software) factor analysis module (Field 2005) was used, specifying the principal component method with varimax rotation (Kaiser 1958). In order to determine a number of factors the Kaiser criterion was applied (Chen et al. 2005). The rotation of the components axis is performed so that components are clearly defined by high 
loadings for some variables and low loadings for others, facilitating the interpretation in terms of original variables. FA is also used as a classification technique, useful for hydrochemical facies investigation and interpretation of their origin (Lawrence and Upchurch 1983). FA can be applied to investigation of groundwater contamination (Subbarao et al. 1995; Grande et al. 1996; Jeong 2001). This study area was evidence of groundwater chemistry transformations due to anthropogenic contamination. This situation is connected mainly to shallow unconfined aquifers but increasingly contamination appears in deep aquifers, covered by complex of geological features in the study area. The investigation of groundwater contamination is complicated (particularly in cases of early phase groundwater contamination) because of changes in groundwater chemistry caused by contamination and natural (geogenic) hydrogeochemical processes overlap.

\section{Results and discussion}

\subsection{Chemistry of groundwater}

Water quality analysis has been carried out for major ions and Hexavalent chromium $\left(\mathrm{Cr}^{6+}\right)$ and Iron $\left(\mathrm{Fe}^{2+}\right)$ of groundwater samples and the analytical results of the chemical analysis and the statistical parameters such as minimum, maximum, mean are presented in table 1 for both pre-monsoon and post-monsoon. And also plotted spatial variations of different constituents in figure $2(\mathrm{a}-\mathrm{g})$. The $\mathrm{pH}$ of groundwater ranges from $6.65-11.49$ and 6.62-11.68 for both seasons. High $\mathrm{pH}$ in groundwater indicates that it is alkaline in nature. Significantly elevated concentration of $\mathrm{pH}$ observed in R1 and R5 inside TCCL is due to the anaerobic conditions (figure 2a). The total dissolved solids (TDS) in groundwater ranges from $174-4522 \mathrm{mg} / \mathrm{l}$ and $94-1854 \mathrm{mg} / \mathrm{l}$ in both pre- and post-monsoon. TDS concentration of groundwater has been found slightly reduced during post-monsoon (figure $2 \mathrm{~b}$ ). The electrical conductivity (EC) in groundwater varies from $272-5520 \mu \mathrm{S} / \mathrm{cm}$ and $268-4100 \mu \mathrm{S} / \mathrm{cm}$ in both pre- and post-monsoon (figure 2c). The elevated concentration of TDS and EC was resulted from domestic sewage water in the Pulianthangal village (R15) and agriculture contamination in the well (R28 and R9) near Palar River in pre-monsoon. There is a considerable amount of dilution of concentration of ions during the postmonsoon due to precipitation (Rao et al. 2011). As per the TDS classification (Fetter 1990), most of the groundwater samples collected during the pre-monsoon and post-monsoon periods belong to brackish type (TDS > $1000 \mathrm{mg} / \mathrm{l}$ ). The groundwater classifications of Freeze and Cherry (1979) and

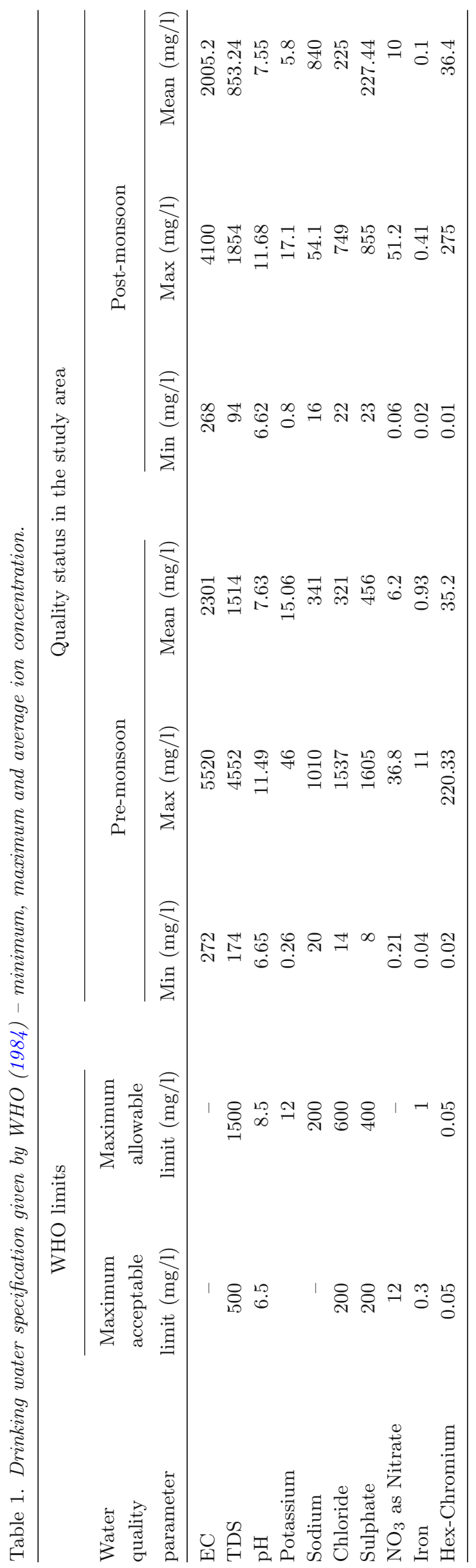




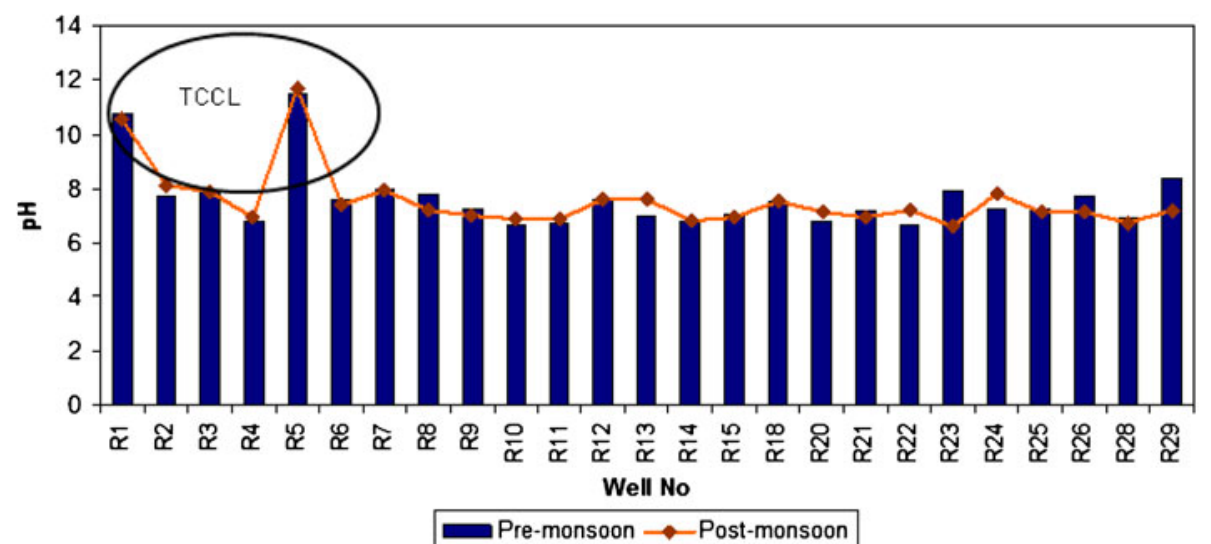

(a)

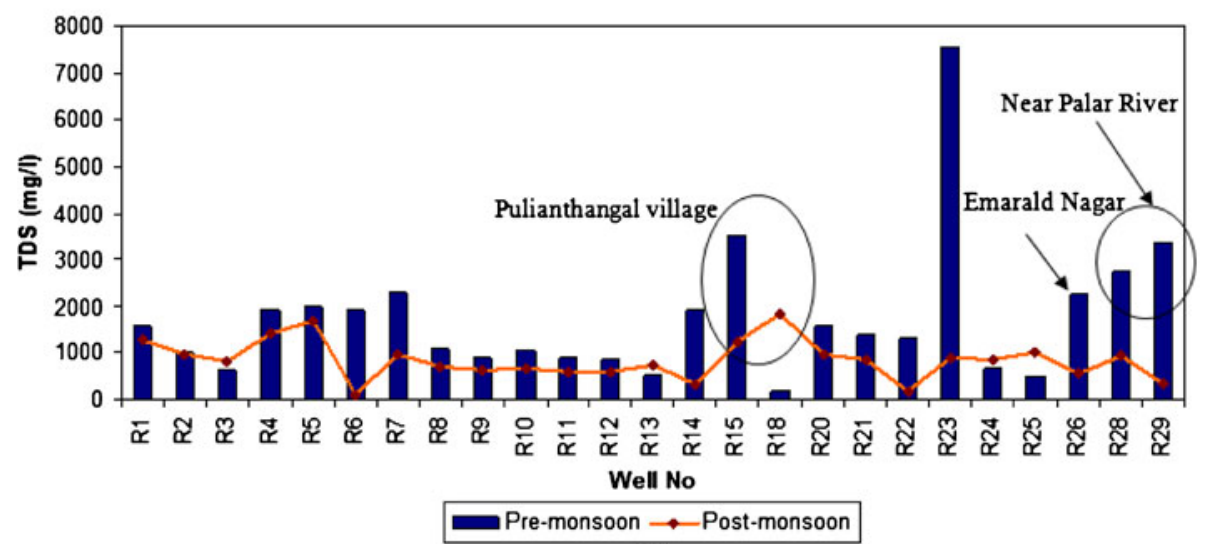

(b)

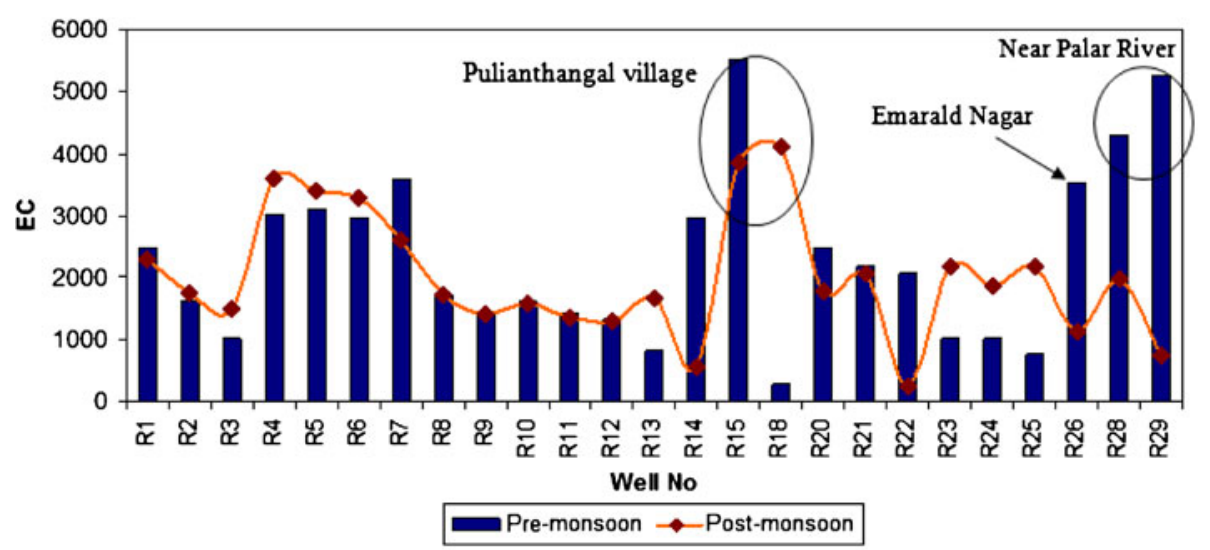

(c)

Figure 2. Spatial variation of (a) $\mathrm{pH},(\mathbf{b}) \mathrm{TDS}(\mathrm{mg} / \mathrm{l}),(\mathbf{c}) \mathrm{EC}(\mu \mathrm{S} / \mathrm{cm}),(\mathbf{d}) \mathrm{Cl}(\mathrm{mg} / \mathrm{l}),(\mathbf{e}) \mathrm{SO}_{4}(\mathrm{mg} / \mathrm{l}),(\mathbf{f}) \mathrm{NO}_{3}-\mathrm{N}(\mathrm{mg} / \mathrm{l})$, (g) K $(\mathrm{mg} / \mathrm{l}),(\mathbf{h}) \mathrm{Na}(\mathrm{mg} / \mathrm{l})$ and (i) $\mathrm{Fe}^{+2}(\mathrm{mg} / \mathrm{l})$ for pre-monsoon and post-monsoon.

Davis and DeWiest (1966) are presented in tables 2 and 3.

The chloride $\left(\mathrm{Cl}^{-}\right)$concentration in groundwater ranges from $14-1537 \mathrm{mg} / \mathrm{l}$ and $22-749 \mathrm{mg} / \mathrm{l}$ in both pre- and post-monsoon. The $\mathrm{Cl}^{-}$concentration also has shown elevated ranges in groundwater during pre-monsoon as compared those of postmonsoon (figure 2d). The elevated concentration of $\mathrm{Cl}^{-}$is seen in the VOC Nagar at well no.
$\mathrm{R} 23$ in pre-monsoon. The sulphate $\left(\mathrm{SO}_{4}\right)$ concentration in groundwater ranges from $8-1605 \mathrm{mg} / \mathrm{l}$ and $23-855 \mathrm{mg} / \mathrm{l}$ in both seasons. $\mathrm{SO}_{4}^{2-}$ concentrations were elevated during pre-monsoon (figure 2e). The pre-monsoon $\mathrm{SO}_{4}^{2-}$ concentration are reported in well nos. R4 (1605 mg/l), R6 (666 mg/l), R7 $(579 \mathrm{mg} / \mathrm{l})$ and R20 (687 mg/l). In post-monsoon season only one well R7 (729 $\mathrm{mg} / \mathrm{l})$ is showing high concentration. Elevated $\mathrm{SO}_{4}^{2-}$ concentration 


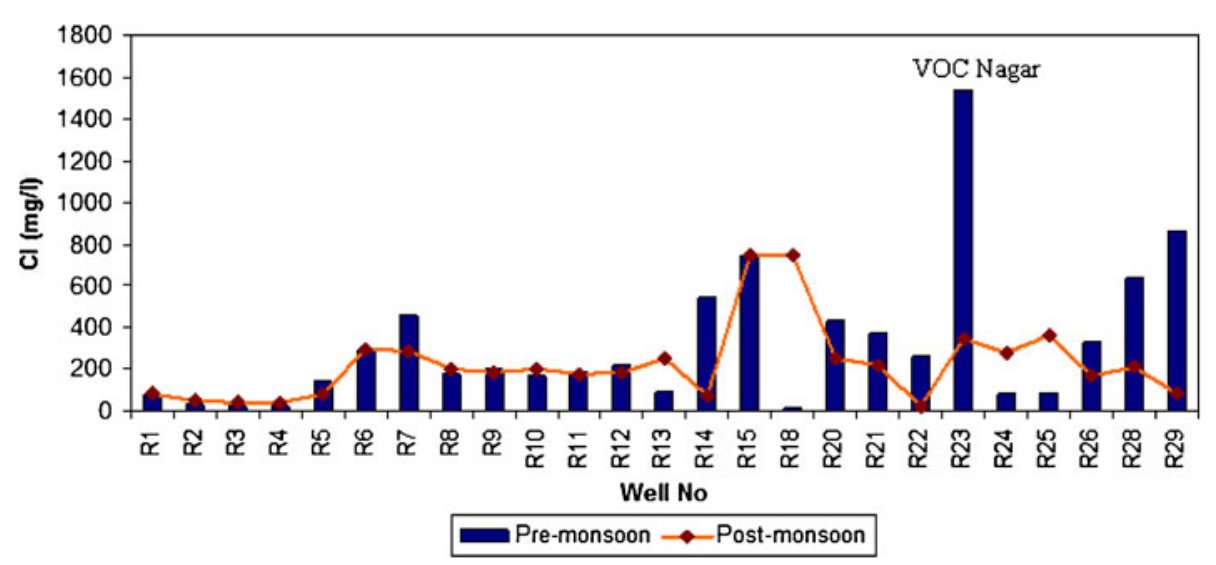

(d)

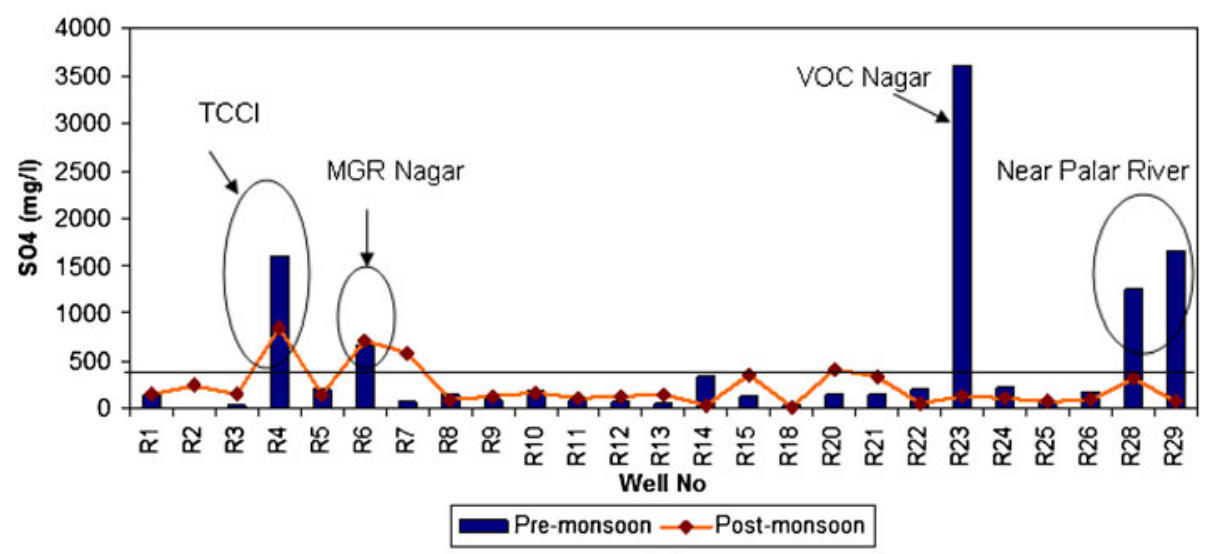

(e)

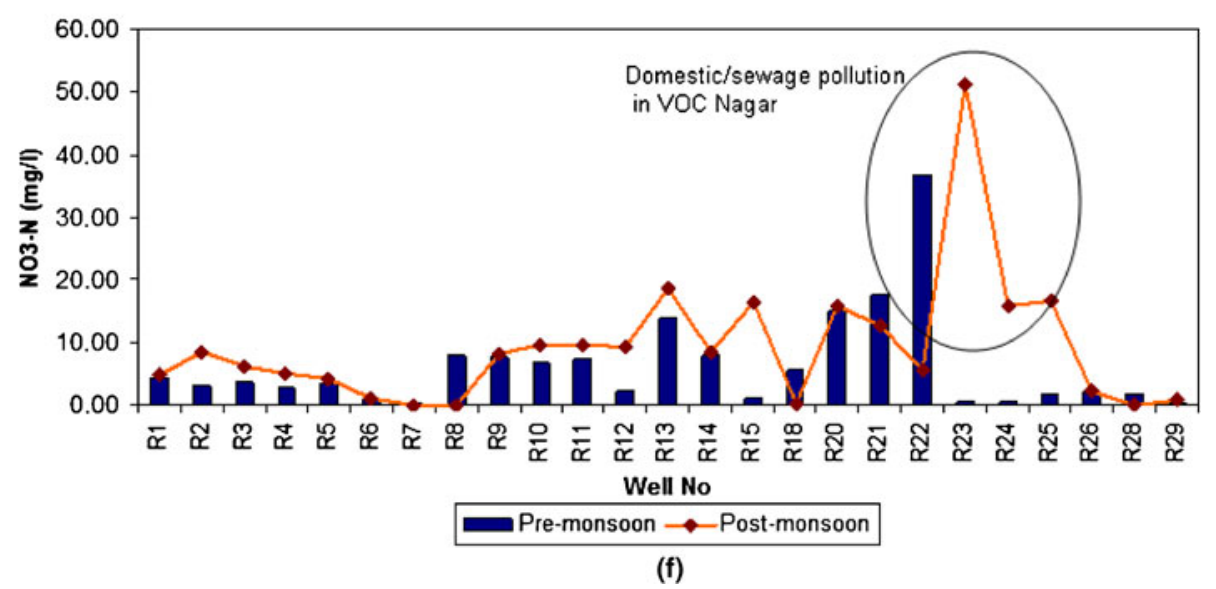

Figure 2. (Continued)

of $1605 \mathrm{mg} / \mathrm{l}$ in groundwater has been reported in well no. R4 inside TCCL. It is possible that the waste sludge in the dump may be contributing as chromium sulphate. Outside the TCCL premises, the well R6, near MGR Nagar, has also reported elevated $\mathrm{SO}_{4}^{2-}$ concentrations of 666 and $725 \mathrm{mg} / \mathrm{l}$, respectively for pre- and post-monsoon. The pre-monsoon $\mathrm{SO}_{4}^{2-}$ concentration in well $\mathrm{R} 20$ $(687 \mathrm{mg} / \mathrm{l})$, located in the premises of SIPCOT Ltd (in an industrial area) has indicated the severe nature of groundwater contamination. Significantly there is no nitrate contamination reported in the groundwater samples except R23 (36.8 mg/l) and R24 (14.2 mg/l) for pre-monsoon and R13 (18.8 mg/l), R20 (15.8 mg/l), R24 (51.2 mg/l), and R25 (16.18 mg/l) in VOC Nagar for post-monsoon, due to the anthropogenic (domestic/sewage) activities (figure $2 \mathrm{f})$. The potassium $\left(\mathrm{K}^{-}\right)$concentrations are varying from $0.26-46 \mathrm{mg} / \mathrm{l}$ and $0.8-17.1 \mathrm{mg} / \mathrm{l}$ for both pre- and post-monsoon. Elevated $\mathrm{K}^{-}$ 


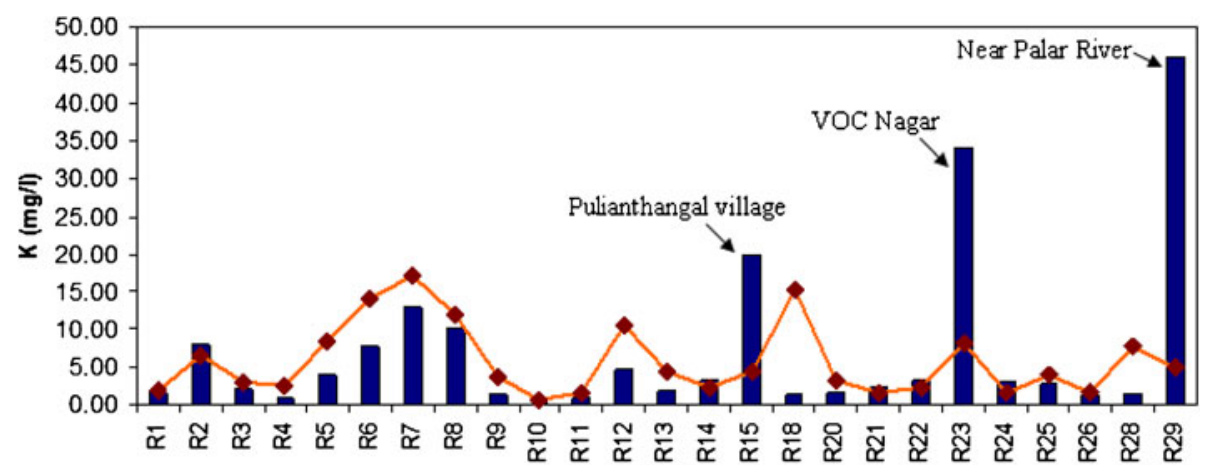

Well No

$\longrightarrow$ Pre-monsoon $\longrightarrow$ Post-monsoon

(g)

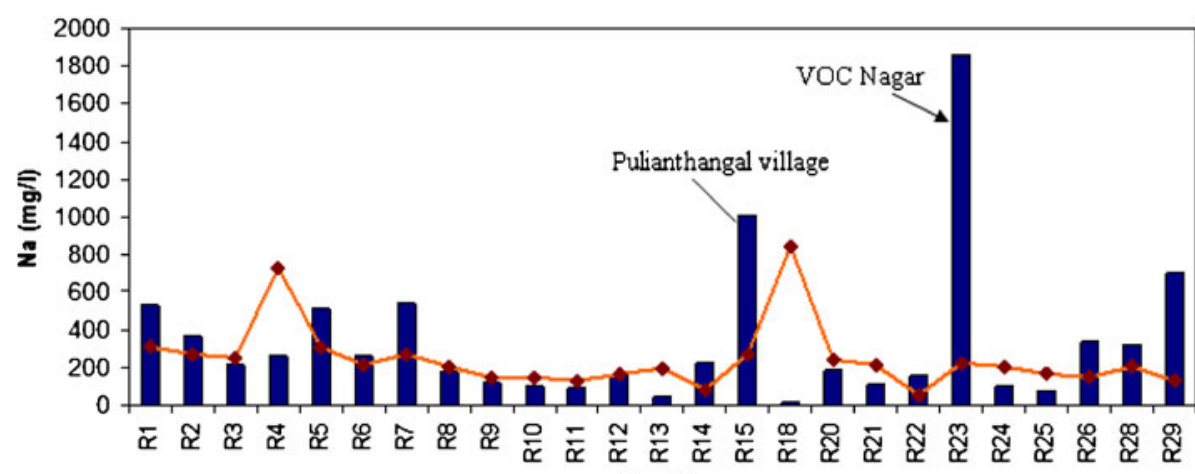

Well No

Pre-monsoon $\longrightarrow$-Post-monsoon

(h)

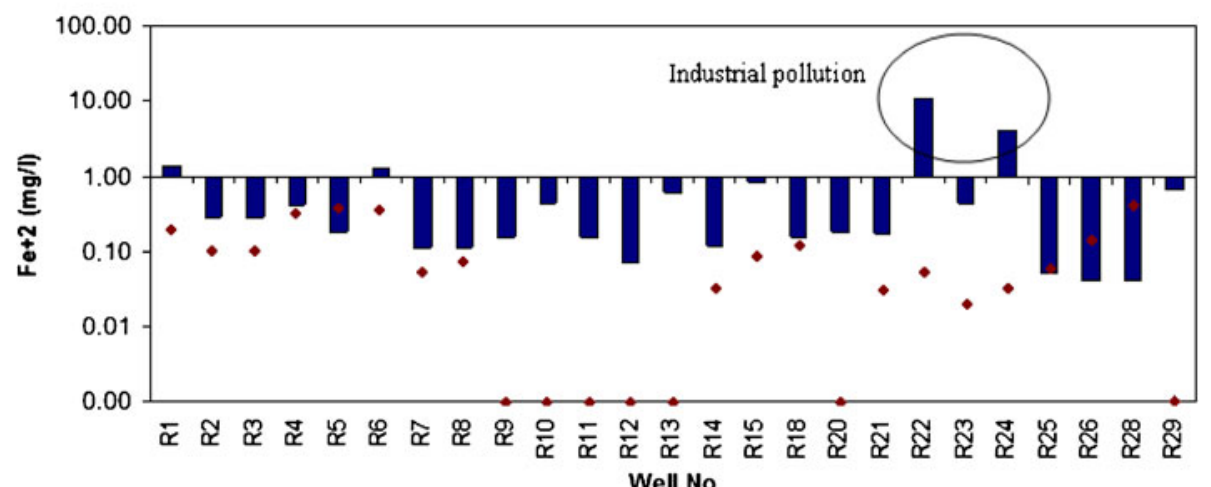

- Pre-monsoon • Post-monsoon

(i)

Figure 2. (Continued)

Table 2. Groundwater classification (Davis and DeWiest 1966).

\begin{tabular}{llll}
\hline TDS $(\mathrm{mg} / \mathrm{l})$ & \multicolumn{1}{c}{ Water quality } & \multicolumn{1}{c}{ Pre-monsoon } & Post-monsoon \\
\hline Up to 500 & Desirable for drinking & $174-497(2)$ & $94-346(4)$ \\
$500-1000$ & Permissible for drinking & $523-905(6)$ & $570-980(15)$ \\
Up to 3000 & Useful for irrigation & $1025-2752(13)$ & $1020-1854(6)$ \\
Above 3000 & Unfit for drinking and irrigation & $3366-4522(3)$ & \\
\hline
\end{tabular}

concentrations are observed in pre-monsoon season at R15 (Pulianthangal village), R23 (VOC Nagar) and R29 (Near Palar River) (figure 2g).
The sodium $\left(\mathrm{Na}^{+}\right)$concentrations in groundwater ranges from $20-1010 \mathrm{mg} / \mathrm{l}$ and $16-54.1 \mathrm{mg} / \mathrm{l}$ in both seasons (figure $2 \mathrm{~h}$ ). $\mathrm{Na}^{+}$was higher in 
Table 3. Groundwater classification (Freeze and Cherry 1979).

\begin{tabular}{llll}
\hline $\operatorname{TDS}(\mathrm{mg} / \mathrm{l})$ & Water quality & Post-monsoon & Pre-monsoon \\
\hline $0-1000$ & Freshwater & $174-905(8)$ & $94-980(19)$ \\
$1000-10,000$ & Brackish water & $1025-4522(16)$ & $1020-1854(6)$ \\
$10,000-100,000$ & Salty water & & \\
$>100,000$ & Brine & & \\
\hline
\end{tabular}

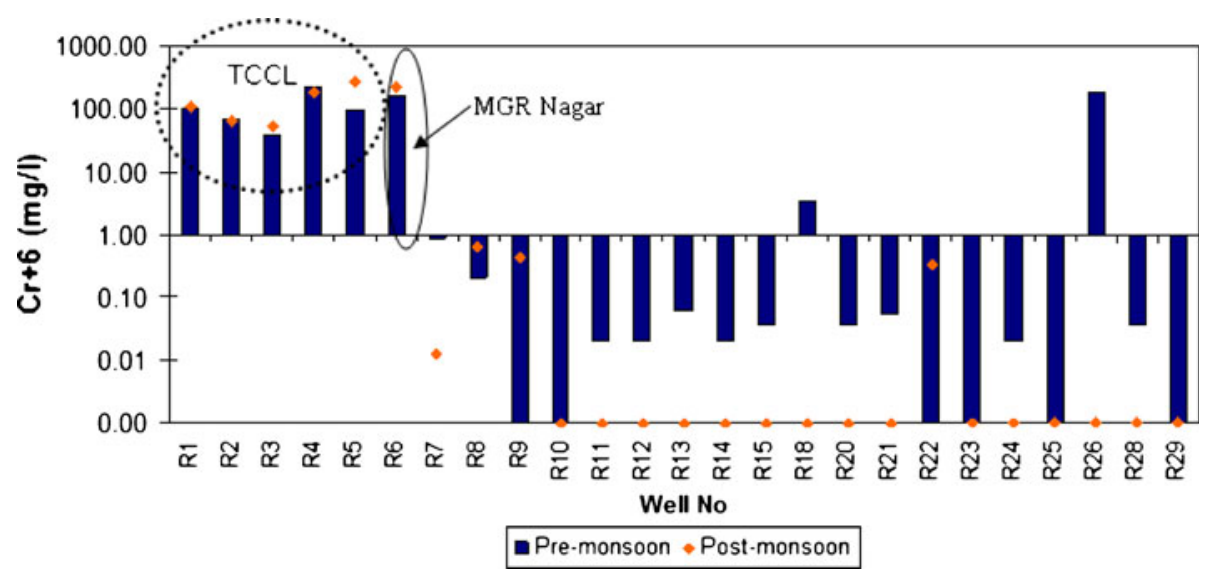

Figure 3. Spatial variation of $\mathrm{Cr}^{+6}(\mathrm{mg} / \mathrm{l})$ for pre-monsoon and post-monsoon.

pre-monsoon season indicating weathering from plagioclase bearing rocks (Srinivasamoorthy et al. 2008; Rao et al. 2011). High concentration of $\mathrm{Na}^{+}$was predicted in the R15 (Pulianthangal village), R23 (VOC Nagar) and R29 (Near Palar River).

\subsection{Metal concentrations}

In the case of iron, the concentration of $\mathrm{Fe}^{2+}$ in many of the stations is higher than the WHO (1984) permitted limit of $0.3 \mathrm{mg} / \mathrm{l}$. The concentration of $\mathrm{Fe}^{2+}$ varying from $0.04-11.0$ and $0.02-0.41 \mathrm{mg} / \mathrm{l}$ for both pre- and post-monsoon (figure 3a). Elevated values of iron concentrations were observed at R1 $(1.36 \mathrm{mg} / \mathrm{l}), \mathrm{R} 6(1.31 \mathrm{mg} / \mathrm{l})$, R10 (0.44 mg/l), R13 (0.6 mg/l), R15 (0.84 mg/l), $\mathrm{R} 22(11.0 \mathrm{mg} / \mathrm{l}) \mathrm{R} 24 \quad(4.13 \mathrm{mg} / \mathrm{l})$ and R25 $(0.45 \mathrm{mg} / \mathrm{l})$, in pre-monsoon. There is a significant elevated concentration observed in the downstream of TCCL (R22) and Maniyampettai colony (R24) in pre-monsoon season.

Chromium occurs in higher concentrations in the wastes from electroplating, paints, dyes, chrome tanning, paper industries, etc. Maximum contaminant level of chromium for the drinking water is $0.05 \mathrm{mg} / \mathrm{l}$ (WHO 1984). The hexavalent chromium $\left(\mathrm{Cr}^{6+}\right)$ concentrations are varying from 0.02 to $220 \mathrm{mg} / \mathrm{l}$ and 0.01 to $275 \mathrm{mg} / \mathrm{l}$ during both pre- and post-monsoon (figure $3 \mathrm{~b}$ ). The wells R1 (103.4-109 mg/l), R2 (69.85-64 $\mathrm{mg} / \mathrm{l})$, R3 (38.58-53 mg/l), R4 (220.33-185 mg/l), R5 (95.6-275 mg/l), R6 (160.9-225 mg/l), R7 (0.9-0.01 mg/l), R18 (3.48-BDL mg/l) in both pre- and post-monsoon. Elevated $\mathrm{Cr}^{6+}$ concentrations were observed in both seasons, due to the chromium dump inside TCCL which is contaminating the downstream area (Rao et al. 2009). The wells R1-R5 are located within the TCCL industrial premise and are highly contaminated with $\mathrm{Cr}^{6+}$ and downstream of R18. High concentration of $\mathrm{Cr}^{6+}$ observed in the Anna Nagar (R26) upstream of the TCCL area due to the leather industrial activities.

\subsection{Groundwater quality and assessment}

Groundwater quality assessment of the study area was carried out to determine its suitability in terms of domestic and agricultural purposes based on the WHO (1984) standards (table 1). The quality of groundwater in the study area is highly influenced by anthropogenic contamination. R1, R2, R3, R4 and R5 samples inside in TCCL premises, 18 near adjacent to TCCL, R6 and R7 in MGR Nagar, R15 in Pulianthangam village, R20 and R21 in SIPCOT industrial area, R23 in VOC Nagar and R24 and R25 in Maniyampettai colony in pre-monsoon 
and post-monsoon seasons exceed TDS concentration recommended by WHO (1984) and ISI (1983). The sodium concentrations exceeded in some locations like R1, R2, R3, R4 and R5 samples inside in TCCL premises, R18 adjacent to TCCL and R7 in MGR Nagar in both seasons due to the sodium salts used in TCCL industry (Rao et al. 2009, 2011). The potassium concentration exceed in pre-monsoon recommended by WHO (1984) in and around TCCL area only. The chloride concentrations in MGR Nagar, VOC Nagar, SIPCOT industrial area and Anna Nagar (R26) were shown elevated values due to leaching migration from upper soil layers due to industrial and domestic activities and dry climates (Srinivasamoorthy et al. 2008). Nitrate as N concentrations are observed in R20 and R21 in pre-monsoon and 13 (VOC Nagar), R20, R24 and R25 in post-monsoon seasons. High nitrate concentrations in groundwater could pose potential hazard to infant health. The consumption of water with high nitrate concentration decreases the oxygen-carrying capacity of blood, causing blue babies or methemoglobinemia (Jeevanandam et al. 2006). High $\mathrm{SO}_{4}^{2-}$ concentration were observed in TCCL (R4), MGR Nagar (R6) and SIPCOT (R20) in pre-monsoon and R7 near MGR Nagar in post-monsoon; it could be possible that the waste sludge in the TCCL (chromium dump) may be contributing chromium sulphate and migrating towards downstream area (Rao et al. 2009).

The iron concentration in nine samples exceeds the maximum permissible limit of $0.3 \mathrm{mg} / \mathrm{l}$ as per WHO (1993) standards in TCCL, VOC Nagar, SIPOT industrial area, Maniyampettai colony and Pulianthangam village. Higher iron content may produce undesirable effects such as astringent taste, discoloration, turbidity, deposits, and growth of iron bacteria in pipes affecting the acceptability of water for domestic use (Das and Borah 1983). The shortage of iron causes a disease called 'anemia' and prolonged consumption of drinking water with high concentration of iron may lead to liver disease called as 'haermosiderosis' (Rajgopal 1984).

The chromium $\left(\mathrm{Cr}^{6+}\right)$ concentration in six samples in and around TCCL and 2 samples in MGR Nagar exceeds the maximum permissible limit of $0.05 \mathrm{mg} / \mathrm{l}$ as per WHO (1993) standards. The study area predominantly composed of granite rocks, where chromium concentration is always below $50 \mathrm{mg} / \mathrm{kg}$, it is not possible to derive such high levels of Cr from rocks (Fendorf 1995; Edmunds and Smedley 1996). Therefore, the source of $\mathrm{Cr}$ appears to be anthropogenic activity from the TCCL. Chromium is an essential trace element, required for the metabolism of lipids and proteins and to maintain a normal glucose tolerance factor. High doses of chromium cause liver and kidney damage and chromium dust is carcinogenic
(SEGH 2001). Chromium can cause allergic reactions in the skin, damage the lungs, and asthma attacks (ATSDR 2005). Chromium is water soluble and extremely irritating and toxic to human body tissue owing to its oxidizing potential and permeability of biological membranes (Anderson 1999).

\subsection{Factor analysis}

R-mode factor analysis was applied to obtain correlations among the hydrochemical constituents of groundwater samples (Brown 1998; Kouping et al. 2006), and all the chemical constituents were plotted (figure 4) for both pre- and post-monsoon. The aim is to evaluate the variables belonging to a specific chemical process and also to find out the dominance and contribution of the major elements in terms of the total dataset. Varimax rotation is a commonly employed method for assisting in factor identification, which was useful, in this application, to place the contaminants on a minimum number of factors. After several trial runs, it was found that extracted five factors in pre-monsoon and four factors in post-monsoon during the analysis and their loading, communalities for each variable, percentage of the variance of each factor, and cumulative percentage of variance are listed in tables 4 and 5. Liu et al. (2003) classified the factor loading as 'strong', 'moderate' and 'week' corresponding to absolute loading values of $>0.75$, $0.75-0.50$ and $0.50-0.40$, respectively. The factors, which best describe the variance of the analysed data (eigen value $>1$ ) and can be reasonably interpreted, were accepted for further analysis. The sum of squared factor loadings (communality) shows how the obtained factors describe variance of particular variables. Finally, factor scores were calculated for each sample. Extreme positive factor scores $(>+1)$ reflect areas most affected, and negative $(<-1)$ reflect areas unaffected by the chemical process represented by the factor. Near-zero scores reflect areas affected to an average degree of the process or factor.

FA of the pre-monsoon data rendered four significant (eigen value $>1$ ) factors explaining $85.9 \%$ of the total variance (table 4). Factor 1 explains $26.8 \%$ of the variance and has strong loadings of $\mathrm{TA}(0.816), \mathrm{Ca}^{2+}(0.834)$ and $\mathrm{Na}^{+}(0.939)$, whereas $\mathrm{SO}_{4}^{2-}(0.635)$ showing moderate loadings. The high loading of TA $(>0.75)$ indicates that sources of major ionic constituents are the poor domestic sewerage system and the tanneries. Chloride ion has higher dominant leaching ion from upper soil layers due to industrial and domestic activities and dry climates (Srinivasamoorthy et al. 2008). Sodium ion in groundwater derives from the incongruent 


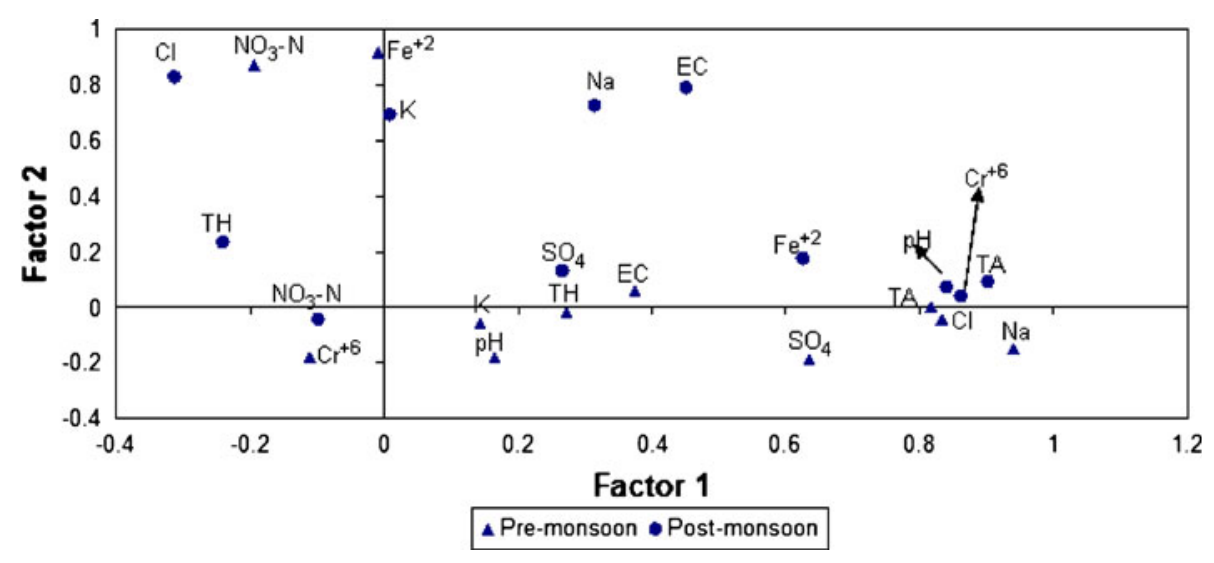

Figure 4. Plot of factor loadings for the first two factors in pre-monsoon and post-monsoon.

Table 4. Factor analysis of groundwater samples in the study area-Pre-monsoon (June 2008).

\begin{tabular}{lcccccc}
\hline Parameter & Factor 1 & Factor 2 & Factor 3 & Factor 4 & Factor 5 & Communalities \\
\hline $\mathrm{pH}$ & 0.166 & -0.181 & -0.802 & 0.144 & 0.261 & 0.792 \\
$\mathrm{EC}$ & 0.375 & 0.061 & 0.001 & 0.446 & 0.618 & 0.725 \\
$\mathrm{TA}$ & 0.816 & 0.001 & -0.307 & -0.227 & 0.21 & 0.855 \\
$\mathrm{Cl}$ & 0.834 & -0.046 & 0.331 & 0.368 & -0.121 & 0.957 \\
$\mathrm{SO}_{4}$ & 0.635 & -0.189 & 0.426 & 0.346 & 0.04 & 0.742 \\
$\mathrm{NO}_{3}-\mathrm{N}$ & -0.193 & 0.871 & 0.125 & -0.113 & -0.176 & 0.856 \\
$\mathrm{Na}$ & 0.939 & -0.149 & -0.044 & 0.184 & 0.016 & 0.94 \\
$\mathrm{~K}$ & 0.143 & -0.06 & -0.05 & 0.966 & -0.023 & 0.96 \\
$\mathrm{TH}$ & 0.272 & -0.021 & 0.806 & 0.099 & 0.478 & 0.962 \\
$\mathrm{Fe}$ & -0.008 & 0.916 & -0.004 & 0.03 & 0 & 0.84 \\
$\mathrm{Cr} 6+$ & -0.11 & -0.182 & -0.02 & -0.141 & 0.874 & 0.83 \\
Eigen values & 2.958 & 1.732 & 1.697 & 1.537 & 1.534 & 13.949 \\
$\%$ of variance & 26.893 & 15.747 & 15.429 & 13.97 & 85.988 & \\
$\mathrm{Cumulative} \%$ & 26.893 & 42.64 & 58.069 & 72.039 & & \\
\hline
\end{tabular}

dissolution of plagioclase in granite, chemical fertilizer, domestic effluents and atmospheric input (Aiuppa et al. 2003; Valdes et al. 2007). The loading of $\mathrm{SO}_{4}^{2-}$ is due to the chromium sulphates used in tannery industries (Rao et al. 2009; Bhardwaj et al. 2010). Factor 2 (tannery pollution factor) explains $15.7 \%$ of variance and has strong loadings of Nitrate as $\mathrm{N}(\mathbf{0 . 8 7 1})$ and $\mathrm{Fe}^{2+}(\mathbf{0 . 9 1 6})$. There was no known lithologic source for Nitrate as $\mathrm{N}$, and generally atmospheric deposition was not considered to be a major source of Nitrate as $\mathrm{N}$ concentrations in the groundwater (Handa 1988), the substantial contribution of Nitrate as $\mathrm{N}$ in the study area was likely resulted from domestic sewage effluents and industrial inputs to groundwater. Factor 3 explains $15.4 \%$ of the variance and has strong negative loading of $\mathrm{pH}(-0.802)$ and strong positive loading (0.806) of TH. Factor 4 explains $13.9 \%$ of the variance and has strong positive loading of $\mathrm{K}(0.966)$. Potassium ion in groundwater often comes from orthoclase and muscovite minerals present in granite, and from pollution sources such as domestic effluents. Factor 5 explains $13.9 \%$ of the variance and has strong positive loading of $\mathrm{Cr}^{6+}$ (0.874) and moderate loading of EC (0.618). Electrical conductivity of groundwater was largely influenced by factor 2; natural processes as well as anthropogenic inputs may determine its level. Electrical conductivity originates from the anthropogenic activities and $\mathrm{Cr}^{6+}$ originate from some common processes in the textile industry. The sources of these trace metals, especially chromium, are the tanneries located in the area.

FA of the post-monsoon data rendered that five factors accounted for $82.3 \%$ of the total variance (table 5). These factors with different factor loadings indicate that different contributions are involved in determining the chemical compositions of groundwater in the study area. Factor 1, accounting for about $29.01 \%$ of the variance 
Table 5. Factor analysis of groundwater samples in the study area - Post-monsoon (December 2008).

\begin{tabular}{lrrrcc}
\hline Parameter & Factor 1 & Factor 2 & Factor 3 & Factor 4 & Communalities \\
\hline $\mathrm{pH}$ & 0.842 & 0.072 & -0.396 & -0.089 & 0.878 \\
$\mathrm{EC}$ & 0.452 & 0.784 & 0.389 & 0.089 & 0.979 \\
$\mathrm{TA}$ & 0.902 & 0.092 & 0.007 & 0.055 & 0.826 \\
$\mathrm{Cl}$ & -0.311 & 0.825 & 0.14 & 0.332 & 0.907 \\
$\mathrm{SO}_{4}$ & 0.268 & 0.127 & 0.854 & -0.2 & 0.858 \\
$\mathrm{NO}_{3}-\mathrm{N}$ & -0.096 & -0.046 & 0.044 & 0.906 & 0.834 \\
$\mathrm{Na}_{\mathrm{K}}$ & 0.315 & 0.723 & 0.086 & -0.12 & 0.644 \\
$\mathrm{TH}$ & 0.009 & 0.693 & 0.036 & -0.362 & 0.613 \\
$\mathrm{Fe}$ & -0.238 & 0.234 & 0.842 & 0.265 & 0.891 \\
$\mathrm{Cr}$ & $6+$ & 0.172 & 0.373 & -0.434 & 0.75 \\
Eigen values & 0.626 & 0.041 & 0.296 & -0.228 & 0.885 \\
$\%$ of variance & 29.06 & 21.961 & 18.222 & 13.149 & \\
Cumulative $\%$ & 29.06 & 51.021 & 69.243 & 82.392 & \\
\hline
\end{tabular}

and was primarily composed of $\mathrm{pH}(0.842)$, TA (0.902), $\mathrm{Cr}^{6+}(0.862) \mathrm{pH}$ and $\mathrm{Fe}^{2+}(0.626)$. TA and $\mathrm{Cr}^{6+}$ constituents are showing strong positive loading (>0.75) and $\mathrm{Fe}^{2+}$ is showing weak loading (0.75-0.50). Factor 2, accounting for about $21.9 \%$ of the variance and was primarily composed of EC (0.784), $\mathrm{Cl}^{-}(0.825), \mathrm{Na}^{+}(0.723)$ and $\mathrm{K}^{+}(0.692)$. EC, $\mathrm{Na}^{+}$and $\mathrm{Cl}^{-}$are showing high positive loading $(>0.75)$ and $\mathrm{K}^{+}$is showing moderate loading (0.75-0.50). Factor 3, accounting for about $18.2 \%$ of the variance and was primarily composed of $\mathrm{SO}_{4}^{2-}(0.854)$ and TH (0.842). Factor 4, accounting for about $13.1 \%$ of the variance and associated with very high loading of Nitrate as N (0.906).

Comparison of FA for the two seasons shows the effect of groundwater recharge caused by monsoon and it appears that the major ion pollution factor shows little change during the post-monsoon season, but there is considerable reduction in pollution load caused by the tannery pollution factor. This is evidenced by the substantial reduction in the concentration of trace metals notably $\mathrm{Cr}^{6+}$ and $\mathrm{Fe}^{2+}$, and major ionic constituents such as $\mathrm{Na}^{+}, \mathrm{Cl}^{-}$and $\mathrm{SO}_{4}^{2-}$ during the post-monsoon season.

\section{Conclusions}

The hydrochemistry of the groundwater varies in relation to different anthropogenic activities, intrusion of polluted domestic sewage water, and seepage of tannery pollutants. The pre-monsoon values indicate that most of the groundwater belongs to the brackish type and it has been found that much of dilution has occurred during the post-monsoon where the TDS values were significantly lowered. Moreover, the TDS values of the groundwater are higher than the permissible limit for both the preand post-monsoon samples. The nitrate and potassium concentrations of pre-monsoon groundwater samples are higher than the WHO, ISI permissible limits in certain places but got diluted in post-monsoon. The result of the trace metal concentrations shows that $\mathrm{Fe}^{2+}$ and $\mathrm{Cr}^{6+}$ are found to be higher than the prescribed limit. The factor analysis of the major ion chemistry of the groundwater reveals five in pre-monsoon and four in pre-monsoon prevalent factors operating in these waters. The major factors which explain the various loadings are precipitation and chemical weathering and anthropogenic. The results show that the groundwater in the study area is affected by the agricultural activities and in the downstream both anthropogenic and chemical weathering factors are found to be significant. The present state of the quality of the Rapine industrial area is of great concern and the higher concentration of toxic metals $\left(\mathrm{Cr}^{6+}\right.$ and $\left.\mathrm{Fe}^{2+}\right)$ may entail various health hazards. Considerable decrease in concentration of cations and anions in the post-monsoon water samples indicates that the dilution factor predominates over the leaching factor. In the downstream of study area, the wells located in MGR Nagar contaminated by the leachate migration from chromium dump site in TCCL. If the laechate migration from chromium dump not intercepted at this stage it would further contaminate the groundwater reservoir posing a major threat to the entire living community of the area. 


\section{Acknowledgements}

Authors are grateful to Director, N.G.R.I., Hyderabad for his continuous encouragement and kind permission to publish this paper. The authors are thankful to CPCB for support of the research and laboratory staff for assistance in analyzing samples.

\section{References}

Aiuppa A, Bellomoa S, Bruscab L, Alessandrob W D and Federico C 2003 Natural and anthropogenic factors affecting groundwater quality of an active volcano (Mt. Etna, Italy); Appl. Geochem. 18 863-882.

Anderson R A 1999 Chromium as an essential nutrient. The chromium File No. 6. Intl Chromium Development Association.

Ansari A A, Singh I B and Tobschall H J 1999 Status of anthropogenically induced metal pollution in the KanpurUnnao industrial region of the Ganga plain, India; Environ. Geol. 381 25-33.

APHA 1998 Standard methods for the examination of water and wastewater (21st edn); Washington DC: American Public Health Association.

ATSDR 2005 Agency for Toxic Substances and Disease Registry; ToxFAQs Chemical Fact Sheets, www.atsdr.cdc. gov/toxfaq.html.

Bhardwaj Vikram, Dhruv Sen Singh and Singh A K 2010 Water quality of the Chhoti Gandak River using principal component analysis, Ganga Plain, India; J. Earth Syst. Sci. 119 117-127.

Briz-Kishore B H and Murali G 1992 Factor analysis for revealing hydrogeochemical characteristics of a water shed; Environ. Geol. Water Sci. 19 3-9.

Brown C E 1998 Applied multivariate statistics in geohydrology and related sciences; Springer, Berlin-HeidelbergNew York.

Chen T B, Zheng Y M, Lei M, Huang Z Ch, Wu H T, Chen H, Fan K K, Yu K, Wu X and Tian Q Z 2005 Assessment of heavy metal pollution in surface soils of urban parks in Beijing, China; Chemosphere 60 542-551.

CLRI 1990 Central Leather Research Institute report on capacity utilization and scope for modernization in Indian tanning industry; Central Leather Research Institute, Chennai, 12p.

Das H B and Borah K 1983 Iron excess in drinking water of Darrang district of Assam and some adjoining areas; Defence Sci. J. 33 31-37.

Davis S N and DeWiest R J 1966 Hydrogeology; New York: Wiley.

Davis J C 2002 Statistics and data analysis in geology; New York: Wiley, 638p.

Edmunds W M and Smedley P L 1996 Groundwater geochemistry and health: An overview; Publicity Publication Wallingford: British Geological Survey, 12p.

Elango L, Kannan R and Senthil Kumar M 2003 Major ion chemistry and identification of hydrogeochemical processes of groundwater in a part of Kancheepuram District, Tamil Nadu, India; Environ. Geosci. 10 157-166.

Fendorf S E 1995 Surface reactions of chromium in soils and waters; Geoderma 67 55-71.

Fetter C W 1990 Applied hydrogeology (New Delhi, India: CBS Publishers \& Distributors).

Field A P 2005 Discovering statistics using SPSS; 2nd edn. London: Sage.
Freeze R A and Cherry J A 1979 Groundwater; PrenticeHall, Englewood Cliffs, NJ, USA, 604p.

Govil P K, Reddy G L N, Krishna A K, Seshu C L V N S, Satya Priya V and Sujatha D 2004 Inventorization of contaminated sites in India, NGRI technical report no: NGRI-2004-EG-421, pp. 54-66.

Grande J A, Gonzalez A, Beltaran R and Sanchez-Rodas D 1996 Application of factor analysis to the study of contamination in the aquifer system of Ayamonte-Huelva (Spain); Ground Water 34(1) 155-161.

GSI 2000 Geology and Mineral Resources of Tamil Nadu; GSI Miscellaneous. Publication No. 30, Part VII, 2nd Rev. edn, 91p.

Handa B K 1988 Content of potassium in groundwater in India; Fertilizer News 33 15-27.

Hem J D 1989 Study and interpretation of the chemical characteristics of natural water; US Geological Survey Water Supply Paper, 2254p.

ISI 1983 Drinking water standard - substances or characteristic affecting the acceptability of water for domestic use; IS, 10500, pp. 1-22.

Jeevanandam M, Kannan R, Srinivasalu S and Rammohan V 2006 Hydrogeochemistry and groundwater quality assessment of lower part of the Ponnaiyar River Basin, Cuddalore district, South India; Environ. Monit. Assess. 132 263-274, doi: 10.1007/s10661-006-9532-y.

Jeong C H 2001 Effect of land use and urbanization on hydrochemistry and contamination of groundwater from Taejon area Korea; J. Hydrol. 253 194-210.

Kaiser H F 1958 The varimax criteria for analytical rotation in factor analysis; Psychrometrika 23 187-200.

Kolpin D W, Barbash J E and Gillion R J 1998 Occurrence of pesticides in shallow groundwater of the United States: Initial results from the national water quality assessment program; Environ. Sci. Tech. 32 558-566.

Kouping C, Jiao J J, Huang J and Huang R 2006 Multivariate statistical evaluation of trace elements in groundwater in a coastal area in Shenzhen, China; Environ. Pollut. $147771-780$.

Lawrence A R and Upchurch S B 1983 Identification of recharge areas using geochemical factor analysis; Ground Water 20(6) 680-687.

Liu C W, Lin K H and Kuo Y M 2003 Application of factor analysis in the assessment of ground water quality in ablackfoot disease area in Taiwan; Sci. Total Environ. 313 77-89.

Matthess G 1982 The Properties of Groundwater; New York: Wiley \& Sons.

Mondal N C and Singh V S 2005 Integrated approach to delineate the contaminated groundwater in the tannery belt: A case study. In: Proceeding of the 2nd Asia Pacific Association of Hydrology and Water Resources Conference, Suntec, Singapore, 2 436-444.

Rao V V S G, Tamma Rao G, Surinaidu L, Ranganathan K and Shukla B P 2009 Groundwater remediation of chromium plume in Ranipet dumpsite; NGRI Tech Rep. No. NGRI-2009-Environ-698, 22p.

Rao G T, Gurunadha Rao V V S, Ranganathan K, Surinaidu L, Mahesh J and Ramesh G 2011 Assessment of groundwater contamination from a hazardous dump site in Ranipet, Tamil Nadu, India; Hydrogeol. J. 19 1587-1598, doi: 10.1007/s10040-011-0771-9.

Rajgopal 1984 Groundwater quality assessment for public policy in India; 1st Annual report. Department of Geography, IOWA University, IOWA, pp. 10-11.

Razack M and Dazy J 1990 Hydrochemical characterization of groundwater mixing in sedimentary and metamorphic reservoirs with combined use of piper's principal and factor analysis; J. Hydrol. 114 371-393. 
Ruiz F, Gomis V and Blasco P 1990 Application of factor analysis to the hydrogeochemical study of a coastal aquifer; J. Hydrol. 119 169-177.

Sankaran S, Rangarajan R, Krishna Kumar K, Saheb Rao S and Smita Humbarde 2009 Geophysical and tracer studies to detect subsurface chromium contamination and suitable site for waste disposal in Ranipet, Vellore District, Tamil Nadu, India; Environ. Earth Sci., doi: 10.1007/s12665-009-0213-3.

Sawyer G N, McMcartly D L and Parkin G F 2003 Chemistry for environmental engineering and science; 5th edn. McGraw Hill, New York, 152p.

SEGH 2001 Environmental Geochemistry and Health Special Issue; 18th European Conference 23(3).

Selvakumar M and Manoharan R 2002 Effect of tannery effluent in groundwater and its control - A case study at Dindigul; Proc. IGC, Dindigul.

Srinivasa Gowd S, Krishna A K and Govil P K 2005 Environmental risk assessment and remediation of soils contaminated due to waste disposal from tannery industries: A case study of Ranipet industrial area, Tamil Nadu, India; Geochim. Cosmochim. Acta 69A 427.

Srinivasa Rao Y, Reddy T V K and Nayudu P T 1997 Groundwater quality in the Niva River basin, Chitoor district, Andhra Pradesh, India; Environ. Geol. 32 56-63.

Srinivasamoorthy K, Chidambaram S, Prasanna M V, Vasanthaviha M, John Peter and Anandhan P 2008 Identification of major sources controlling groundwater chemistry from a hard rock terrain - A case study from Mettur taluk, Salem district, Tamil Nadu, India; J. Earth Syst. Sci. 117(1) 49-58.
Subramanian K S and Selvan T A 2001 Geology of Tamil Nadu and Pondicherry (Bangalore: Geological Society of India), 192p.

Subbarao C, Subbarao N V and Chandu S N 1995 Characterisation of groundwater contamination using factor analysis; Environ. Geol. 28(4) 175-180.

Suk H and Lee K 1999 Characterization of a groundwater hydrochemical system through multivariate analysis: Clustering into groundwater zones; Groundwater $\mathbf{3 7}$ $358-366$.

Thangarajan M, Subrahmanyam K and Srimannarayana M 1999 Preliminary assessment of groundwater pollution due to tannery effluents in Kodaganar river basin, Dindigul district, Tamil Nadu, India; In: Proceeding on International Association of Hydrogeologists, Hydrogeology and Land Use Management, Bratislava, Slovak Republic, pp. 629-632.

Usunoff E J and Guzman A G 1989 Multivariate analysis in hydrochemistry. An example of the use of factor and correspondence analysis; Groundwater 17 27-34.

Valdes D, Dupont J P, Laignel B, Ogier S, Leboulanger T and Mahler B J 2007 A spatial analysis of structural controls on Karst groundwater geochemistry at a regional scale; J. Hydrol. $340244-255$.

WHO 1984 Guideline of drinking quality; World Health Organization, Washington DC, pp. 333-335.

WHO 1993 Guidelines for drinking water quality; vol. 1, 2nd edn, Geneva, ISBN 924154460.

Wu T L 1980 Dissipation of the herbicides atrazine and alachlor in a Maryland corn field; J. Environ. Quality 9 459-465. 